\title{
TRANSFER TEKNOLOGI PENCEGAHAN BUSUK BUAH DENGAN PENGGUNAAN PERANGKAP LALAT BUAH
}

\section{TECHNOLOGY TRANSFER FRUIT ROT PREVENTION BY USING FRUIT FLY TRAPS}

\section{Eko Apriliyanto}

\author{
Program Studi Agroindustri, Politeknik Banjarnegara \\ Jl. Raya Madukara Km. 2 Kenteng, Banjarnegara, 53482 \\ Email: okeapriliyanto@gmail.com \\ (Diterima 22-10-2020; Disetujui 18-02-2021)
}

\begin{abstract}
ABSTRAK
Pemanfaatan pekarangan rumah untuk budidaya tanaman buah banyak dilakukan oleh masyarakat saat ini. Kendala produksi tanaman buah salah satunya yaitu adanya busuk buah yang disebabkan oleh hama lalat buah (Bactrocera sp.). Penggunaan atraktan berbahan metil eugenol belum banyak dikenal oleh masyarakat umum. Kegiatan transfer teknologi upaya pencegahan busuk buah dilakukan dengan pemberian materi tentang gejala dan penyebab busuk buah dan praktik upaya pencegahan busuk buah menggunakan perangkap lalat buah berbasis metil eugenol. Kegiatan diawali dengan pre-test tentang pengetahuan busuk buah. Kegiatan dilanjutkan dengan praktik, dan diskusi. Setelah kegiatan selesai peserta melaksanakan post-test untuk mengukur kemampuan anggota Aurora tentang pengetahuan busuk buah. Peserta pertemuan rutin Aurora (Alumni SMP Negeri 2 Rakit, Banjarnegara Tahun 2020) belum mengalami peningkatan pengetahuan berdasarkan hasi pre-test dan post-tes yang dilakukan tentang gejala, penyebab, dan upaya pencegahan busuk buah. Peserta memiliki keterampilan cara pembuatan perangkap lalat buah dengan bahan aktif metil eugenol.
\end{abstract}

Kata kunci: busuk, lalat buah, metil eugenol, pencegahan

\section{ABSTRACT}

The use of house yards for the cultivation of fruit trees is widely practiced by the community today. One of the constraints to fruit crop production is the presence of fruit rot caused by fruit fly pests (Bactrocera sp.). The use of attractants made from methyl eugenol has not been widely known by the general public. The technology transfer activity for preventing fruit rot is carried out by providing material about the symptoms and causes of fruit rot and the practice of preventing fruit rot using fruit fly traps based on methyl eugenol. The activity began with a pre-test on knowledge of fruit rot. The activity was continued with practice and discussion. After the activity is complete, the participants carry out a post-test to measure the ability of Aurora members about fruit rot knowledge. Participants in the Aurora routine meeting (Alumni of SMP Negeri 2 Rakit, Banjarnegara in 2020) have not experienced an increase in knowledge based on the results of the pre-test and post-test carried out about the symptoms, causes, and efforts to prevent fruit rot. Participants have the skills to make fruit fly traps with the active ingredient methyl eugenol.

Key words: rot, fruit flies, methyl eugenol, prevention

\section{PENDAHULUAN}

Aurora (Alumni SMP Negeri 2 Rakit Lulus Tahun 2000) merupakan forum alumni yang lingkup kegiatannya berupa kegiatan sosial kemasyarakatan. Sebelumnya SMP Negeri 2 Rakit dengan nama SLTP Negeri 2 Rakit pada saat tahun 2000 tersebut. Aurora 
Transfer Teknologi Pencegahan Busuk Buah Dengan Penggunaan Perangkap Lalat Buah Eko Apriliyanto

melakukan banyak kegiatan setelah ada Whatsapp Group (WAG) sejak tanggal 25 Oktober 2016. Awalnya berupa kegiatan beberapa alumni untuk merintis adanya forum alumni, selanjutnya melakukan beberapa pertemuan-pertemuan yang dilakukan dari salah satu rumah alumni ke rumah alumni lainnya secara tidak terjadwal. Saat itu hanya untuk kegiatan temu kangen sesama alumni. Pada kegiatan seelumnya sekitar 10 orang saja yang aktif pada pertemuan-pertemuan alumni tersebut.

Jumlah anggota Aurora secara keseluruhan yaitu 348 alumni. Adapun jumlah anggota Aurora yang aktif di WAG sebanyak 85 orang. Komunikasi melalui WAG saat ini menjadi lebih efektif dan efisien. Saat ini seluruh alumni tidak hanya berdomisili pada wilayah kecamatan Rakit, Punggelan, atau Wanadadi sesuai domisili asal peserta didik saat masih aktif di sekolah menengah. Sebaran alumni meliputi wilayah Banjarnegara, Purbalingga, Cilacap, Yogyakarta, Jabodetabek, Lampung, Palembang, dan Kalimantan. Umumnya alumni berdomisili sesuai dengan tempat kerjanya masing-masing. Sebagian besar anggota Aurora berdomisili di Banjarnegara.

Pekerjaan anggota Aurora saat ini juga beragam, sebagian besar melaksanakan wirausaha, lainnya sebagai buruh, petani, karyawan swasta, PNS, dan TNI. Sebagian besar anggota Aurora yang perempuan menjadi ibu rumah tangga. Beragamnya jenis pekerjaan saat ini bukan menjadi penghalang untuk tetap adanya kebersamaan seluruh anggota. Perbedaan latar belakang pekerjaan juga umumnya sesuai dengan latar belakang pendidikan. Sebagian besar anggota Aurora berpendidikan SMA sederajat. Adapun jenjang pendidikan tertinggi saat ini yaitu S2 sebanyak 2 orang.

Sebagian besar anggota Aurora berdomisili di wilayah pedesaan. Oleh karena itu, bidang pekerjaan yang paling banyak yaitu bersinggungan dengan kegiatan pertanian. Lokasi rumah di desa menjadikan sebagian besar anggota Aurora memiliki pekarangan rumah yang cukup untuk melakukan kegiatan pertanian. Kegiatan pertanian yang mudah dilaksanakan antara lain untuk menanam bunga, sayuran, dan buah. Bahkan sebagian besar memiliki tanaman buah di pekarangan rumah. Pengelolaan tanaman buah yang dilakukan oleh anggota Aurora umumnya belum dilakukan secara maksimal. Tanaman buah dibiarkan tumbuh, tanpa ada upaya-upaya pengelolaan tanaman dengan baik.

Beberapa kendala dalam budidaya tanaman buah di lahan pekarangan berupa, kerontokan bunga, kerontokan buah, keterlambatan berbunga, dan adanya busuk buah. Salah satu kendala utama dalam pengelolaan tanaman buah berupa busuk buah. Anggota Aurora banyak yang belum mengetahui upaya untuk pencegahan atau pengendalian busuk buah tersebut. Oleh karena itu, perlu adanya penyuluhan tentang pencegahan busuk buah. 
Adanya busuk buah yang menyerang menjadi pembatas dalam pemenuhan hasil panen yang optimal untuk tanaman pekarangan rumah. Beberapa anggota Aurora, selain hasil panen buah digunakan untuk konsumsi sendiri, juga ada yang digunakan untuk tambahan penghasilan. Faktor pembatas budidaya buah yang sering dialami masyarakat yaitu adanya serangan busuk buah. Sebagian besar masyarakat belum paham tentang penyebab busuk buah. Beberapa jenis buah yang sering ditanam di pekarangan rumah yaitu jambu air, jambu biji, belimbing, rambutan, kelengkeng, durian, dan lain-lain. Perlu adanya pemberian informasi pengetahuan tentang penyebab busuk buah. Hal ini dapat menjadi dasar pengetahuan bagi anggota Aurora dalam melaksanakan tindaklanjut pengelolaan tanaman buahnya.

Masa pandemi covid-19 menjadikan masyarakat berupaya melaksanakan kemandirian pangan. Salah satu keunggulan tanaman buah di pekarangan rumah dapat memberikan kontribusi untuk peningkatan penghasilan juga. Lebih-lebih, jenis buah umumnya banyak mengandung vitamin yang saat ini banyak dibutuhkan untuk peningkatan ketahanan tubuh. Oleh karena itu, peningkatan hasil panen buah dapat sebagai kegiatan yang sangat relevan di masa pandemic covid-19 ini.

Upaya pemecahan masalah busuk buah dapat berupa adanya penyuluhan tentang busuk buah untuk masyarakat, khususnya anggota Aurora. Penyuluhan tentang pencegahan busuk buah dapat dilakukan pada pertemuan rutin Aurora yang dilaksanakan setiap 3 bulan. Informasi tentang penyebab, gejala, dan upaya pencegahan busuk buah sebagai upaya peningkatan hasil buah yang berkualitas dan dapat mengalami peningkatan kuantitas buahnya juga. Upaya pemecahan masalah dari kurangnya pengetahuan anggota Aurora tentang pencegahan busuk buah dapat dilakukan dengan kegiatan pemberian materi berupa penyuluhan dan pelatihan atau praktik langsung melakukan upaya pencagahan busuk buah dapat dilihat pada Tabel 1 .

Tabel 1. Kerangka pemecahan masalah

\begin{tabular}{|c|c|c|}
\hline Kondisi sekarang & Kegiatan yang dilakukan & Kondisi yang diharapkan \\
\hline $\begin{array}{l}\text { 1. Pengetahuan tentang } \\
\text { gejala dan penyebab } \\
\text { busuk buah masih } \\
\text { rendah. }\end{array}$ & $\begin{array}{l}\text { 1. Penyuluhan tentang } \\
\text { gejala dan penyebab } \\
\text { busuk buah. }\end{array}$ & $\begin{array}{l}\text { 1. Adanya pengetahuan dan } \\
\text { pemahaman tentang gejala } \\
\text { dan penyebab busuk buah. }\end{array}$ \\
\hline $\begin{array}{l}\text { 2. Pengetahuan dan } \\
\text { keterampilan upaya } \\
\text { pencegahan busuk } \\
\text { buah masih rendah. }\end{array}$ & $\begin{array}{l}\text { 2. Penyuluhan dan } \\
\text { pelatihan pembuatan } \\
\text { cara pencegahan busuk } \\
\text { buah. }\end{array}$ & $\begin{array}{l}\text { 2. Adanya pengetahuan dan } \\
\text { keterampilan upaya } \\
\text { pencegahan busuk buah } \\
\text { dengan cara murah dan } \\
\text { mudah. }\end{array}$ \\
\hline
\end{tabular}


Permasalahan yang dimiliki oleh anggota Aurora tentang kegiatan budidaya tanaman di pekarangan rumah yaitu: a) anggota Aurora belum memiliki pengetahuan tentang gejala dan penyebab busuk buah, dan b) belum memiliki pengetahuan dan keterampilan tentang upaya pencegahan busuk buah. Kegiatan ini bertujuan memberikan transfer teknologi tentang pencegahan busuk buah pada tanaman di pekarangan rumah.

\section{BAHAN DAN METODE}

Kegiatan ini dilaksanakan pada tanggal 5 Juli 2020 pukul 09.00 s.d. 12.00 WIB di rumah Sdr. Sukirno, Desa Binorong. RT 02, RW 01, Bawang, Banjarnegara pada pertemuan rutin 3 bulanan Aurora. Khalayak sasaran kegiatan ini yaitu anggota Aurora yang hadir dengan jumlah peserta sebanyak 10 orang. Kegiatan transfer teknologi upaya pencegahan busuk buah dilakukan dengan: 1) pemberian materi tentang gejala dan penyebab busuk buah, dan 2) pelatihan atau praktik upaya pencegahan busuk buah. Alatalat yang digunakan untuk pembuatan perangkap lalat buah yaitu gunting, pisau, botol air mineral ukuran $600 \mathrm{ml}$, kawat, dan alat tulis. Bahan-bahan yang digunakan yaitu metil eugenol (Petrogenol 800 1) dan kapas. Metode yang digunakan dalam kegiatan ini yaitu pemberian materi untuk seluruh peserta dari anggota Aurora. Kegiatan diawali dengan pretest tentang pengetahuan busuk buah. Kegiatan dilanjutkan dengan praktik pembuatan perangkap lalat buah, dan diskusi. Setelah kegiatan selesai peserta melaksanakan post-test untuk mengukur kemampuan anggota Aurora tentang pengetahuan busuk buah.

\section{HASIL DAN PEMBAHASAN}

Salah satu kendala dalam budidaya tanaman buah yaitu adanya busuk pada buah. Busuk buah dapat disebabkan oleh serangan pathogen berupa jamur dan bakteri atau lalat buah. Perlu adanya upaya pencegahan agar tidak terjadi busuk buah tersebut. Upaya pencegahan harus diketahui dahulu penyebab busuk buah tersebut. Busuk buah yang disebabkan oleh jamur atau bakteri umumnya dapat diketahui lebih cepat karena gejala awal busuk dari luar. Sedangkan busuk buah yang disebabkan oleh lalat buah banyak yang belum mengetahuinya, karena seringkali bagian luar buah diduga baik, tetapi bagian dalam buah sudah diserang oleh larva lalat buah.

Lalat buah (Bactrocera sp) merupakan salah satu jenis hama penting yang berasosiasi pada buah-buahan dan menyerang langsung pada bagian tanaman yang dipanen. Serangan lalat buah dimuali pada saat tanaman memasuki fase awal pembuahan hingga masa panen, dengan gejala adanya bekas tusukan hingga buah busuk dan gugur 
(Wahyuni dan Deornay, 2018). Ruswandi (2017) menambahkan bahwa kerusakan oleh lalat buah mengakibatkan munculnya gejala tusukan lalat buah berupa titik hitam pada buah serta gugurnya buah sebelum mencapai matang yang diinginkan, sehingga produksi buah kualitas maupun kuantitas menurun.

Penelitian Sumarmin et al (2011) pada tanaman jeruk menunjukkan bahwa kombinasi metil eugenol dan ekstrak jeruk mempengaruhi feeding strategy dari lalat buah Bactrocera dorsalis. Tingkah laku atau aktivitas dari lalat buah seperti searching, grounding, gathering, dan learning untuk sampai ke umpan membutuhkan waktu yang berbeda-beda. Arma et al (2018) menyatakan bahwa salah satu pengendalian yang aman bagi lingkungan dan cukup efektif dalam menekan populasi lalat buah adalah penggunaan metil eugenol yang mengandung unsur nabati yang disukai oleh lalat buah. Penggunaan metil eugenol sebagai atraktan lalat buah dapat menjadi alternatif penggunaan pestisida kimia yang diharapkan dapat mengendalikan hama tanpa menimbulkan masalah lingkungan.

Pembutan perangkap lalat buah berdasarkan penelitian Susanto et al (2018) yang dimodifikasi sebagai berikut:

1. Perangkap dibuat dari botol air mineral berukuran $600 \mathrm{ml}$, pada bagian atas badan botol $\pm 7 \mathrm{~cm}$ dilubangi sebanyak dua lubang berhadapan sebagai tempat masuknya lalat buah.

2. Tutup botol diberi lubang kecil untuk memasukkan kawat sepanjang $\pm 50 \mathrm{~cm}$ sebagai media untuk menggantungkan kapas yang telah diberi metil eugenol dan juga untuk menggantungkan perangkap di tanaman buah.

3. Botol perangkap yang sudah siap, kemudian diisi larutan deterjen sebanyak $200 \mathrm{ml}$.

4. Pemasangan perangkap di lahan berada di bawah tajuk tanaman.

Peserta kegiatan pertemuan rutin Aurora dengan tingkat pendidikan sebagian besar SMA sederajat dan S1 yang masing-masing 40\%, sedangkan tingkat pendidikan SMP yaitu $20 \%$ (Gambar 1). Beberapa bidang pendidikan ada yang tidak sesuai dengan bidang pekerjaannya. Beberapa peserta, selain bekerja sesuai yang tercantum pada Gambar 2, sebagian besar berasal dari keluarga petani, oleh karena banyak dari anggota Aurora yang memiliki lahan pekarangan rumah untuk budidaya tanaman tertentu. Jenis tanaman buah merupakan jenis tanaman yang banyak diusahakan oleh anggota Auorora. 


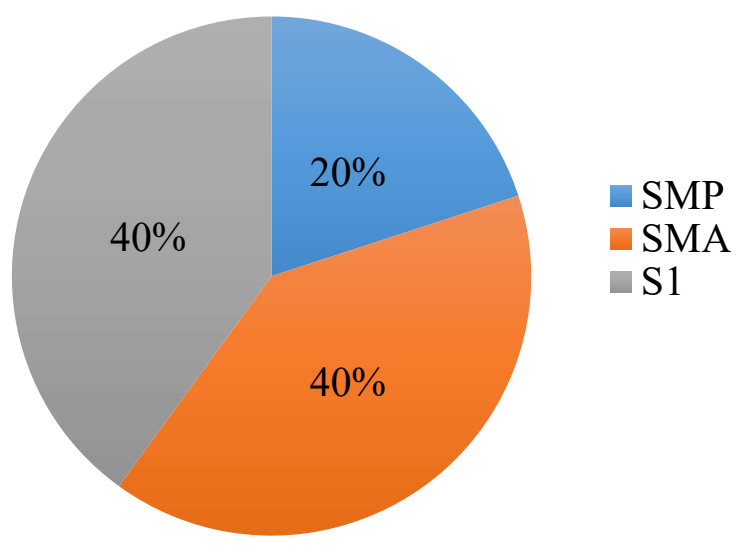

Gambar 1. Tingkat pendidikan peserta pertemuan rutin Aurora.

Adapun pekerjaan peserta pertemuan rutin Aurora sebagian besar sebagai karyawan swasta dan guru masing-masing 40\%, sedangkan lainnya sebagai wiraswasta sebanyak $20 \%$ (Gambar 2). Ada satu peserta yang bidang pekerjaannya sebagai karyawan swasta di bidang pertanian, sedangkan lainnya karyawan pada sektor jasa, industri bulu mata, dan pelayaran. Walaupun pekerjaan peserta pertemuan rutin Aurora sebagian besar bukan di bidang pertanian, tetapi mereka umumnya memiliki lahan pekarangan rumah yang berpotensi untuk budidaya tanaman buah.

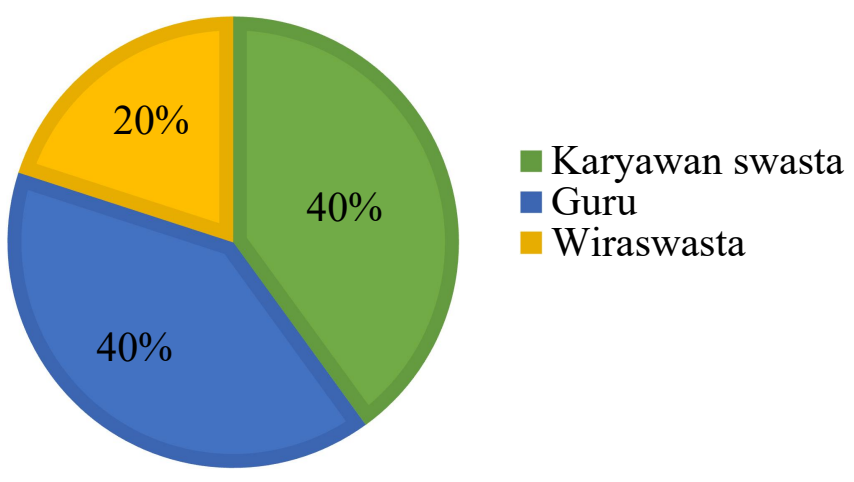

Gambar 2. Pekerjaan peserta pertemuan rutin Aurora.

Hasil analisis uji t pada kegiatan pre-test dan post-test yang dilakukan menunjukkan $P$ value $(0,269)$ lebih dari 0,05 (Tabel 2). Hal tersebut menunjukkan bahwa hasil pre-test dan post-test menunjukkan tidak berbeda nyata. Tingkat pengetahuan peserta pada saat pre-test dan post-test menunjukkan belum mengalami peningkatan. Rerata nilai pre-test dan post-test berturut-turut yaitu 66 dan 72,222. Tingkat pengetahuan peserta tentang gejala, penyebab, dan upaya pencegahan busuk buah masih rendah. Hal ini seiring dengan 
bidang pekerjaan anggota Aurora yang sebagian besar tidak di bidang pertanian. Pengetahuan tentang busuk buah masih terbatas.

Tabel 2. Hasil analisis uji t pada pre-test dan pos-test

\begin{tabular}{lrr}
\hline Keterangan & Pre-test & Post-test \\
\hline Mean & 66 & 72,222 \\
Variance & 804,444 & 172,839 \\
Observations & 10 & 10 \\
Pooled Variance & 488,642 & \\
Hypothesized Mean Difference & 0 & \\
df & 18 & \\
t Stat & $-0,629$ & \\
P $(T<=t)$ one-tail & 0,269 & \\
t Critical one-tail & 1,734 & \\
P $(T<=t)$ two-tail & 0,537 & \\
$\mathrm{t}$ Critical two-tail & 2,100 & \\
\hline
\end{tabular}

Kegiatan pertemuan rutin Aurora dengan pemberian materi sudah dilaksanakan dari dua pertemuan sebelumnya. Materi yang disampaikan pada pertemuan rutin berasal dari anggota Aurora. Materi yang disampaikan juga disediakan dalam bentuk leaflet untuk memudahkan peserta memahami materinya. Antusisme peserta kegiatan dapat diketahui dari banyaknya peserta yang bertanya tentang penyebab busuk buah yang berasal dari lalat buah. Sebagian besar peserta belum mengetahui tentang penyebab utama busuk buah.

Kegiatan praktik pembuatan perangkap lalat buah menggunakan botol bekas air mineral yang diberi atraktan metil eugenol juga diminati oleh peserta. Masyarakat sekitar tempat tinggal peserta pertemuan banyak yang belum mengetahui cara ramah lingkungan dalam pencegahan busuk buah. Hasil pembuatan perangkap lalat buah langsung dipasang pada tanaman jambu air yang berada di rumah lokasi kegiatan. Peserta dapat melihat langsung lalat buah yang datang ke perangkap dalam waktu tidak lebih dari 5 menit dari pembuatan perangkap.

\section{KESIMPULAN DAN SARAN}

Peserta pertemuan rutin Aurora belum mengalami peningkatan pengetahuan berdasarkan hasi pre-test dan post-test yang dilakukan tentang gejala, penyebab, dan upaya pencegahan busuk buah. Peserta memiliki keterampilan cara pembuatan perangkap lalat buah dengan bahan aktif metil eugenol. Perlu adanya pendampingan yang berkelanjutan tentang upaya peningkatan produksi tanaman buah di pekarangan rumah. 


\section{DAFTAR PUSTAKA}

Arma, R., Sari, D.E., dan Irsan. (2018). Identifikasi hama lalat buah (Bactrocera sp) pada tanaman cabe. Jurnal Agrominansia, 3(2): 109-120.

Ruswandi, A. (2017). Nilai ekonomi pengendalian lalat buah pada mangga gedong gincu: studi kasus di Desa Jembar Wangi Kecamatan Tomo, Sumedang. CR Journal, 3(1): 25-36.

Sumarmin, R., Syukur, U., dan Setiawan, E.D. (2011). Pengaruh kombinasi petragenol dan ekstrak jeruk terhadap feeding strategy lalat buah Bactrocera dorsalis. Jurnal Saintek, 3(1): 70-77.

Susanto, A., Natawigena, W.D., Puspasari, L.T., Neng Inne Nur Atam, N.I.N. (2018). Pengaruh penambahan beberapa esens buah pada perangkap metil eugenol terhadap ketertarikan lalat buah Bactrocera dorsalis kompleks pada pertanaman mangga di Desa Pasirmuncang, Majalengka. Jurnal Perlindungan Tanaman Indonesia, 2(2): 150-159.

Wahyuni, S., Deornay, P.B. (2018). Aplikasi beberapa ekstrak tanaman sebagai bahan perangkap lalat buah (Bactrocera sp.). AGRICA, 11(2): 95-104. 